\title{
Effect of organic amendments on nitrate leaching mitigation in a sandy loam soil of Shkodra district, Albania
}

\author{
Erdona Demiraj, ${ }^{1}$ Angela Libutti, ${ }^{2}$ Jamarbër Malltezi, ${ }^{1}$ Evan Rroço, ${ }^{3}$ Ferdi Brahushi, ${ }^{1}$ \\ Massimo Monteleone, ${ }^{2}$ Sulejman Sulçe ${ }^{1}$
}

\begin{abstract}
${ }^{1}$ Department of Agro-Environment and Ecology, Faculty of Agriculture and Environment, Agriculture
University of Tirana, Albania; ${ }^{2}$ Department of Science of Agriculture, Food and Environment, University of Foggia, Italy; ${ }^{3}$ Department of Plant Science and Technologies, Faculty of Agriculture and Environment, Agriculture University of Tirana, Albania
\end{abstract}

\begin{abstract}
European lacustrine systems are frequently exposed to nitrate $\left(\mathrm{NO}_{3}{ }^{-}\right)$pollution causing eutrophication processes. An example of these lakes is Shkodra Lake, a large, shallow lake shared by Albania and Montenegro, in the Balkans Peninsula. Shkodra Lake is a natural sink that collects $\mathrm{NO}_{3}{ }^{-}$from agricultural activities, widely diffused in the surrounding area. The additions of wheat straw and biochar have been suggested to increase soil $\mathrm{NO}_{3}{ }^{-}$retention of agricultural lands. To better understand the role of these two organic soil amendments in mitigating $\mathrm{NO}_{3}{ }^{-}$leaching from arable lands, a pot experiment using a representative sandy loam soil of the Skodra Lake basin was performed. More specifically, a greenhouse experiment with Lolium multiflorum L. and Zea mays L., was carried out for three months, to evaluate the concentrations of $\mathrm{NO}_{3}{ }^{-}-\mathrm{N}$ in leachate and the cumulative leaching losses of $\mathrm{NO}_{3}{ }^{-}$ $-\mathrm{N}$, after wheat straw $\left(10 \mathrm{Mg} \mathrm{ha}^{-1}\right)$ and biochar $\left(10 \mathrm{Mg} \mathrm{ha}^{-1}\right)$ soil addition, under the same rate of NPK fertiliser $\left(300 \mathrm{~kg} \mathrm{ha}^{-1}\right)$. The effect of the two organic amendments on nitrate retention, was evaluated according to two methods: i) Soil $\mathrm{NO}_{3}{ }^{-}-\mathrm{N}$ leaching with distilled water; and ii) Soil $\mathrm{NO}_{3}{ }^{-}-\mathrm{N}$ extraction with $2 M \mathrm{KCl}$. The leached $\mathrm{NO}_{3}{ }^{-}-\mathrm{N}$ and the "Potentially Leachable» $\mathrm{NO}_{3}{ }^{-}-\mathrm{N}(2 \mathrm{M}$ $\mathrm{KCl}$ extraction) were respectively determined. $\mathrm{N}$ uptake by plants, as well as the Nitrogen Use Efficiency were also calculated. A
\end{abstract}

Correspondence: Angela Libutti, Department of Science of Agriculture, Food and Environment, University of Foggia, via Napoli 25,71122, Foggia, Italy.

Tel.: +39.0881.589128.

E-mail: angela.libutti@unifg.it

Key words: $\mathrm{NO}_{3}{ }^{-}-\mathrm{N}$ leaching; NPK fertiliser; sandy loam soil; Shkodra Lake; wheat straw; wheat straw biochar.

Received for publication: 25 October 2017.

Revision received: 5 December 2017.

Accepted for publication:11 December 2017.

(C) Copyright E. Demiraj et al., 2018

Licensee PAGEPress, Italy

Italian Journal of Agronomy 2018; 13:116

doi:10.4081/ija.2018.1136

This article is distributed under the terms of the Creative Commons Attribution Noncommercial License (by-nc 4.0) which permits any noncommercial use, distribution, and reproduction in any medium, provided the original author(s) and source are credited. retention effect on nitrate was found in Lolium multiflorum L. and wheat straw treatments compared to control, by reducing leached $\mathrm{NO}_{3}{ }^{-}-\mathrm{N}$ almost to $35 \%$. In SBFL (soil+biochar+fertiliser+Lolium) treatment, biochar effectively reduced the total amount of nitrate in leachate of $27 \%$ and $26 \%$ compared to SFL (soil+fertiliser+Lolium) and SSFL (soil+straw+fertiliser+Lolium) treatments, respectively. The potentially leachable $\mathrm{NO}_{3}{ }^{-}-\mathrm{N}$ was two to four times higher than the leached $\mathrm{NO}_{3}{ }^{-}-\mathrm{N}$. The amount of potentially leachable $\mathrm{NO}_{3}{ }^{-}-\mathrm{N}$ per hectare ranged from 220 in $\mathrm{SL}$ (soil+Lolium) treatment, to $500 \mathrm{~kg} \mathrm{ha}^{-1}$ in SFL. N plant uptake values ranged from $18.16 \mathrm{mg} \mathrm{kg}^{-1}$ in the non- fertilised treatment to $58.06 \mathrm{mg} \mathrm{kg}^{-1}$ soil in SSFM (soil+straw+fertiliser+maize) treatment. The NUE showed a similar trend (from 0 in the non-fertilised treatment to $47.9 \%$ in SSFM). Results indicated a mitigating action of biochar on leaching of $\mathrm{NO}_{3}^{-}-\mathrm{N}$ (leached up to $100 \mathrm{~kg}$ $\mathrm{ha}^{-1}$ ), despite the retention effect of the two different amendments applied.

\section{Introduction}

Nitrate $\left(\mathrm{NO}_{3}{ }^{-}\right)$pollution of surface and groundwater is considered one of the most important water quality issues worldwide (Nolan, 2001; Puckett et al., 2011). Since the end of the 1950s, $\mathrm{NO}_{3}{ }^{-}$concentrations in surface water and in groundwater is constantly increasing (Billen and Garnier, 1999; Birgand et al., 2007). Increase of $\mathrm{NO}_{3}{ }^{-}$concentration in surface water can produce an increase in primary production and therefore anoxic conditions, promoting the eutrophication of water bodies (Vitousek et al., 1997; Rivett et al., 2008). Lakes are among the most sensitive surface water bodies, where the load of macronutrients causes more and more frequent pollution and eutrophication processes (Durand et al., 2011). Eutrophication in European lakes has been a major concern for decades (Schindler, 2006). Nitrogen (N) concentrations in lakes vary widely, depending on the intensity of human perturbation of the land in the surrounding basin; $\mathrm{N}$ loading is also highly variable, depending on the relative contribution of terrestrial sources, such as fertilisation and its management. According to Durand et al. (2011), the annual $\mathrm{N}$ loads into the basin of 40 European lakes studied vary from $<0.02$ to $29 \mathrm{~kg} \mathrm{~N} \mathrm{ha}^{-1}$. The nutrient load delivered to aquatic ecosystems depends strongly on the hydrological processes. Especially, the relative importance of different water pathways in the transfer of the various $\mathrm{N}$ forms from terrestrial to aquatic systems plays an important role (Molenat and Gascuel, 2002; Jordan and Smith, 2005).

$\mathrm{NO}_{3}{ }^{-}$is highly soluble within the soil water solution, poorly adsorbed by the soil particles and therefore prone to be leached 
away by the water percolating along the soil profile. $\mathrm{NO}_{3}{ }^{-}$leaching depletes soil fertility, limits the nitrogen utilisation efficiency by the plants, reduces crop yields and represents a significant economic cost for farmers (Libutti and Monteleone, 2017). A fraction of the total $\mathrm{N}$ applied to agricultural land, that is not taken up by plant roots, could moves in soluble form from the soil to surface waters or migrates into groundwaters, polluting the water with nitrates, nitrites or ammonia, as well as reducing the economic efficiency of fertilisers (Vitousek et al., 1997; Carpenter et al., 1998). In 1991, the European Union (EU) adopted the Nitrates Directive $91 / 676 / C E E$, with the aim to protect water quality by preventing nitrate leaching from agricultural activities and promoting the adoption of a code for Good agricultural practices (Libutti and Monteleone, 2017). Although the Nitrates Directive has been implemented in all EU Member States and continues to deliver pollution control, diffuse nitrogen pollution remains problematic. The data on the quality of European water resources (EEA, 2015) highlight that water quality has improved, although concentrations of nutrients in many places are still high and affect the water status. In regions with intensive agriculture production, diffuse nitrogen pollution is still high, resulting in continued eutrophication problems. High $\mathrm{NO}_{3}{ }^{-}$concentration in waters also impacts on human health, because of the associated risk of diseases, like gastrointestinal cancer in adults (Wolfe and Patz, 2002) and methahemoglobinemia in infants (Ward et al., 2005). To prevent this potential human health hazard, the World Health Organisation (WHO) established a contaminant level that should not exceed $50 \mathrm{mg}$ $\mathrm{NO}_{3}{ }^{-} \mathrm{L}^{-1}$ in drinking water (WHO, 2004).

In order to mitigate $\mathrm{NO}_{3}^{-}$leaching from agricultural fields effective agronomic solution must be developed. Soil incorporation of wheat straw, is very long studied as an efficient tool to retain $\mathrm{NO}_{3}{ }^{-}$in the soil (Nishio et al., 2003; Huang et al., 2004; Shindo et al., 2005). The use of a relatively new carbonaceous product such as biochar, as a potential mean to increase this retention, could be also very useful to reduce $\mathrm{NO}_{3}{ }^{-}$losses from agricultural soils and improve nitrogen utilisation efficiency for a sustainable crop production (Laird et al., 2010; Singh et al., 2010; Libutti et al., 2016). Wheat (Triticum aestivum L.) straw residues are an agricultural by-product that plays an important role in building up soil organic matter, increase soil fertility (Lou et al., 2011; Tong et al., 2014; Monteleone et al., 2015) and enhance soil retention of inorganic nitrogen forms, especially nitrate (Thomsen and Christensen, 1998; Döring et al., 2005). These agronomic advantages can be accomplished by adding to the soil wheat straw residues, alone or mixed with mineral $\mathrm{N}$ fertiliser which are very important in improving the enzymatic activity of soil microorganisms (Garg and Bahl, 2008). Previous studies (Meisinger and Delgado, 2002) indicated that wheat straw residues induced a net $\mathrm{N}$ immobilisation during the initial stages, and released $\mathrm{N}$ at later stages, largely depending on several biotic and abiotic factors. It has been reported that application of crop residues reduces $\mathrm{N}$ losses due to a slower cycling pool that caused greater $\mathrm{N}$ retention in soil amended with crop residue (73\%) than with $\mathrm{N}$ fertiliser $(26 \%)$, (Delgado, 2002).

Biochar, a stable and recalcitrant organic carbon compound, is the charred by-product of a thermochemical process (pyrolysis or gasification), which consists essentially in the heating of agricultural biomass in the complete or near absence of oxygen, in order to capture combustible gases. The oils and gases from pyrolysis can be used for energy production; the biochar can provide a useful co-product for the improvement of many soil characteristics (Laird et al., 2009; Monlau et al., 2016).

A number of studies, carried out in open field (Steinbess et al.,
2009; Haider et al., 2017) in pots experiment (Lehmann et al., 2003; Buecker et al., 2016), using leaching columns (Yao et al., 2012; Bradley et al., 2015; Kanthle et al., 2016) or laboratory experiments (Libutti et al., 2016), indicated that biochar is an effective option of nitrate leaching mitigation. However, the impact of crop residue and biochar addition on soil $\mathrm{N}$ retention in agricultural soils are poorly understood. In a field experiment including the addition to the soil of wheat straw, biochar pyrolysed from wheat straw, and wheat straw plus its biochar, $\mathrm{Hu}$ et al. (2014) found higher soil $\mathrm{NO}_{3}{ }^{-}$concentrations in the treatment with biochar. Oppositely, Chen et al. (2012), in a laboratory incubation experiment aiming to investigate the effects of direct incorporation of either wheat straw or its biochar into a cultivated soil, showed that biochar could not effectively immobilise $\mathrm{NO}_{3}{ }^{-}$in the soil. These contradictory results suggest that straw-based biochar might have different effects on $\mathrm{N}$ leaching and retention in heavily fertilised cropland soils and its property of nitrate leaching mitigation need to be studied and verified.

The aim of the present study was to evaluate the effect of two different soil organic amendments on $\mathrm{NO}_{3}{ }^{-}-\mathrm{N}$ retention, according to two methods: i) soil $\mathrm{NO}_{3}{ }^{-}-\mathrm{N}$ leaching with distilled water; and ii) soil $\mathrm{NO}_{3}{ }^{-}-\mathrm{N}$ extraction with $2 \mathrm{M} \mathrm{KCl}$. More specifically, the effect of the addition to a representative sandy loam soil of the Skodra Lake basin (Albania) of wheat straw and biochar from wheat straw on the retention of soluble mineral form of $\mathrm{N}$ was tested in a pot experiment, under controlled conditions.

\section{Materials and methods}

\section{The study area}

Shkodra Lake, the largest lake in the Balkans Peninsula, is located about $20 \mathrm{~km}$ from the Adriatic cost $\left(42^{\circ} 04^{\prime} 03^{\prime \prime} \mathrm{N} ; 19^{\circ} 30^{\prime}\right.$ 47" E), on the border between Albania in the south and Montenegro in the north. It covers a surface from approximately 370 to $600 \mathrm{~km}^{2}$ and has a volume from approximately 1.7 to $4 \mathrm{~km}^{3}$, depending on the seasonal fluctuations between dry and wet periods. It is approximately $5 \mathrm{~m}$ above sea level and mean depth is about $5 \mathrm{~m}$, but can be as much as $60 \mathrm{~m}$ in isolated sublacustrine groundwater springs (Skarbøvik et al., 2014). Because of the wide range of endemic, rare or endangered plant and animal species it gives shelter, Lake Shkodra and its extensive associated wetlands are listed as one of 24 transboundary wetland sites of International value (EEA 1995), and are internationally recognised as a site of significance and importance according to the Ramsar Convention (1995). The Montenegrin side of the basin of Shkodra Lake has been proclaimed a National Park in 1983, while the Albanian side is a protected area Managed natural reserve, since 2005. Due to its importance, the lake has been a subject of numerous investigations, providing numerous physical, chemical and biological background data including environmental studies (Perovic et al., 2004; Rakocevic-Nedovic and Hollert, 2005). It is an ecologically sensitive water body where the biodiversity is under anthropogenic pressing and water quality is threatened mainly from loading of macronutrients used in agriculture (Malollari et al., 2012). The watershed of Shkodra Lake is characterised by concave topography, with slopes that range between 3 and $10 \%$ and a surrounding average elevation of $770 \mathrm{~m}$ a.s.1. (Dhora, 2016). The climate in the study area is Mediterranean, with the highest and lowest temperatures occuring respectively in July-August and December-January and an annual average precipitation of $750 \mathrm{~mm}$ (over a 50-year 
period), concentrated in two rainy seasons, spring and autumn (IGEWE, 2016). The watershed is affected by a high erosion processes. As a result, the parent material of the surrounding agricultural fields is mainly colluvial, calcareous, porous and waterproof. Shkodra Lake is the receiving water body for several large rivers and numerous small streams draining the surrounding catchment area. Due to the karstic nature of the watershed geology, the lake also receives significant input from numerous sub-lacustrine springs, which deliver waters percolating through adjacent agricultural lands (Rastall et al., 2004).

Regarding the land use, on the Albanian side of Shkodra Lake, the main activities of the population are agriculture and animal husbandry; the lands are prevalently cultivated with arable, vegetables and fruits crops. The agricultural activity is very intensive and includes the use of high crops fertilisation. Fertilisers applied by farmers to crops are easily leached out from the soil by rainwater and irrigation water causing a deterioration of lake water quality. Beside the intensive agricultural activity in the fields north of Shkodra (Figure 1), the large amount of waste, urban water, brought to the lake negatively affects the water quality and intensifies eutrophication of the Lake too (Dhora et al., 2012; Dhora, 2016). Indeed, other serious problems of the area are linked to the solid waste dumped throughout the territory along the riverbanks and the outlet of the sewage waters from towns and villages directly to the lake, cause an enrichment of waters with nutrients and chemical detergents increasing the eutrophication of waters (Cullaj et al., 2005). Serving as an agricultural field, this part of the Lake is the most ecologically sensible and economically important one (Mesi, 2013).

\section{Experimental design}

The pot experiment was carried out at Greenhouse Research Station, Agriculture University of Tirana), Albania and the applied experimental treatments were following Table 1. Seven treatments (T) with four replications (r) were compared: T1 = bare soil (S); T2 $=$ soil + Lolium multiflorum $\mathrm{L} .(\mathrm{SL}) ; \mathrm{T} 3=$ soil + wheat straw $(\mathrm{SS}) ;$ $\mathrm{T} 4=$ soil $(\mathrm{S})+\mathrm{NPK}$ fertilisation $(\mathrm{F})+$ Lolium multiflorum L. (L); $\mathrm{T} 5=$ soil + wheat straw $(\mathrm{SS})+\mathrm{NPK}$ fertilisation $(\mathrm{F})+$ Lolium multiflorum L. (L); T6 = soil + wheat Straw (SS) + NPK fertilisation $(\mathrm{F})+$ Zea mays L. (90 day cycle) $(\mathrm{M}) ; \mathrm{T} 7=\operatorname{soil}(\mathrm{S})+$ biochar from wheat straw (B) + NPK fertilisation $(\mathrm{F})+$ Lolium multiflorum L. (L). The soil used in the experiment was taken in Gruemira village $\left(42^{\circ} 09^{\prime} 52,10^{\prime \prime} \mathrm{N}, 19^{\circ} 30^{\prime} 59,43^{\prime \prime} \mathrm{E}\right)$, part of the Koplik municipality (Figure 1) in Malesia e Madhe District, in a deluvional Regosol (Calcaric) (WRB, Updated, 2015). Koplik is a municipality in the North-Western Albania, close to the border of Montenegro. Its territory lay within the Lake Shkodra basin. The municipality has an overall area of 930 ha, out of which 690 ha of urban land, and manages $2.7 \mathrm{~km}$ of Shkodra Lakeshore. The soil sampled in Gruemira village is one of the representative soils of the fields north of Shkodra, together with Regosols (especially Calcaric Regosol) and Luvisols (mainly Calcaric). The soil was collected from the cultivated layer $(0-30 \mathrm{~cm}$ depth) of a farmland, in five points along two crossing diagonals. Before experiment started, stones and crop residues were removed from the collected soil, which was well mixed, air dried, crushed, passed through a 5 mm sieve and mixed thoroughly. The soil was then used for filling the plastic pots (22 $\mathrm{cm}$ in diameter and $24 \mathrm{~cm}$ high) used in the

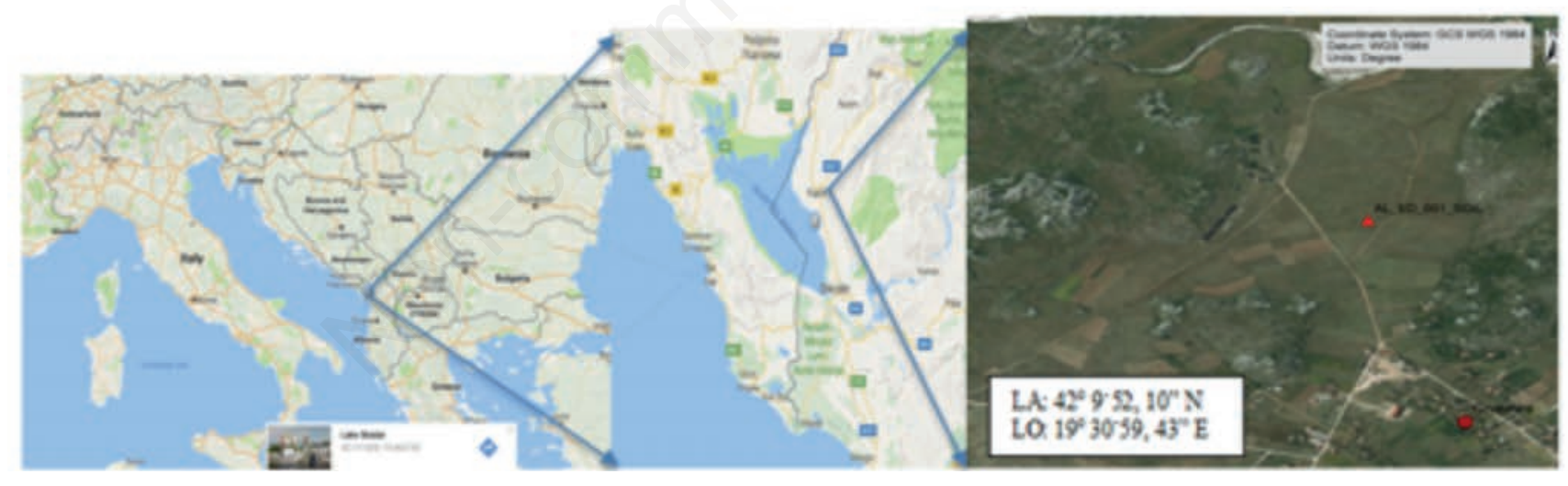

Figure 1. Map of Shkodra Lake and soil sampling place in Gruemira Village, as indicated by the red point AL_ED_001_Soil, with geographic coordinates.

Table 1. Experimental treatments.

\begin{tabular}{|c|c|c|c|c|c|c|c|}
\hline Treatment & $\begin{array}{c}\text { Bare soil } \\
\text { T1/S }\end{array}$ & $\begin{array}{c}\text { Soil + Lolium } \\
\text { multiflorum L. } \\
\text { T2/SL }\end{array}$ & $\begin{array}{c}\text { Soil }+ \\
\text { wheat straw } \\
\text { T3/SS }\end{array}$ & $\begin{array}{c}\text { Soil + NPK + } \\
\text { Lolium multiflorum L. } \\
\text { T4/SFL }\end{array}$ & $\begin{array}{c}\text { Soll + wheat straw + } \\
\text { NPK + Lolium multiflorum L. } \\
\text { T5/SSFL }\end{array}$ & $\begin{array}{c}\text { Soil + wheat straw + } \\
\text { NPK + Zea mays L. } \\
\text { T6/SSFM }\end{array}$ & $\begin{array}{c}\text { Soil + biochar + NPK + } \\
\text { Lolium multiflorum L. } \\
\text { T7/SBFL }\end{array}$ \\
\hline Replication & $\begin{array}{l}S^{1 r} \\
S^{2 r} \\
S^{3 r} \\
S^{4 r}\end{array}$ & $\begin{array}{l}S^{1}{ }^{1 r} \\
S L^{2 r} \\
S L^{3 r} \\
S L^{4 r}\end{array}$ & $\begin{array}{l}\text { SS } 1 \mathrm{r} \\
\text { SS }^{2 \mathrm{r}} \\
\mathrm{SS}^{3 \mathrm{r}} \\
\text { SS }^{4 \mathrm{r}}\end{array}$ & $\begin{array}{l}\text { SFL }^{1 \mathrm{r}} \\
\text { SFL }^{2 \mathrm{r}} \\
\text { SFL }^{3 \mathrm{r}} \\
\text { SFL }^{4 \mathrm{r}}\end{array}$ & $\begin{array}{l}\text { SSFL }^{1 \mathrm{r}} \\
\text { SSFL }^{2 \mathrm{r}} \\
\text { SSFL }^{3 \mathrm{r}} \\
\text { SSFL }^{4 \mathrm{r}}\end{array}$ & $\begin{array}{l}\text { SSFM }^{1 \mathrm{r}} \\
\text { SSFM }^{2 \mathrm{r}} \\
\text { SSFM }^{3 \mathrm{r}} \\
\text { SSFM }^{4 \mathrm{r}}\end{array}$ & $\begin{array}{l}\text { SBFL }^{1 \mathrm{r}} \\
\text { SBFL }^{2 \mathrm{r}} \\
\text { SBFL }^{3 \mathrm{r}} \\
\text { SBFL }^{4 \mathrm{r}}\end{array}$ \\
\hline
\end{tabular}

$1 \mathrm{r}, 2 \mathrm{r}, 3 \mathrm{r}, 4 \mathrm{r}$, replications for each experimental treatment. 
experiment (Figure 2). The pots, bottom packed with washed gravel with a diameter of $1 \mathrm{~cm}\left(1 \mathrm{~kg} \mathrm{pot}^{-1}\right)$ and filled with soil $\left(7 \mathrm{~kg} \mathrm{pot}^{-1}\right)$, were arranged in the seven experimental treatments with four replicates.

In May 2015, T2, T4, T5 and T7 pots were planted with ryegrass (three grams of seeds pot ${ }^{-1}$ ), T6 pots with maize (three seeds pot $^{-1}$. The choice of maize and ryegrass crops followed the options usually applied by farmers in the study area. These two crops were cultivated since the 90 's by farmer cooperatives, due to the climate and the soil physico-chemical properties which created the most favorable conditions for an optimal crop yield performance.

NPK fertiliser $\left(15 \% \mathrm{~N}: 15 \% \mathrm{P}_{2} \mathrm{O}_{5}: 15 \% \mathrm{~K}_{2} \mathrm{O}\right)$ was applied at rate of $300 \mathrm{~kg} \mathrm{ha}^{-1}$. In T2, T4, T5 and T7 fertilisation of reygrass was divided into three doses, corresponding to $3.90 \mathrm{~g} \mathrm{pot}^{-1} \mathrm{dose}^{-1}$. The first fertilisation was carried out at 2-3-leaf stage, 2 weeks after sowing. The second fertilisation, with the same amounts of fertiliser, was applied 1 week after first harvest, which was 1 month after planting, and the same procedure was followed for the third dose of fertiliser ( 1 week after second harvest, which was 2 months after planting). In T6, fertilisation of maize was divided into two doses, corresponding to $5.80 \mathrm{~g} \mathrm{pot}^{-1} \mathrm{dose}^{-1}$. The first fertilisation was directly applied after planting and the second at the 8-leaf stage. Fertilisation was carried out according to the local standard farming techniques as reported by INSTAT and Regional Directorate of Agriculture in Shkodra. The pots were held at a moisture equal to $75 \%$ of field capacity, based on the method of water field capacity (WFC) (Klute A, 1986), adding distilled water $\left(\mathrm{H}_{2} \mathrm{O}\right)$ based on gravimetric method as WFC was calculated in advance. Soil pots were checked daily and water loss was replenished by bringing the pots back to weight. Nitrogen use efficiency (NUE) was calculated as above ground biomass dry matter produced per unit of $\mathrm{N}$-fertiliser and $\mathrm{N}$-amendments applied.

Wheat straw was preliminary grinded at $<0.2 \mathrm{~cm}$ and then applied at a dose of $10 \mathrm{Mg} \mathrm{ha}^{-1}$ (on dry weight basis), corresponding to $40 \mathrm{~g} \mathrm{pot}^{-1}$, in T3, T5 and T6. Many studies have shown that wheat straw is rich in organic material and soil nutrients (Saroa and Lal, 2003; Tan et al., 2007; Lee, 2010) and the addition of crop residues to cultivated soils helps to improve the soil quality and productivity due to its favourable effects on soil properties (Mulumba and Lal, 2008). $\mathrm{N}$ concentration in wheat straw is $0.39 \%$ or $3.90 \mathrm{~g} \mathrm{~kg}^{-1}$ (Khan et al., 2012).

Biochar from wheat straw was applied at a dose of $10 \mathrm{Mg} \mathrm{ha}^{-1}$ (on dry weight basis) in T7, from which $40 \mathrm{~g}$ of biochar were mixed with $400 \mathrm{~g}$ of soil, previously exceeded $2 \mathrm{~mm}$ sieve, and then well mixed in $6600 \mathrm{~g} 5 \mathrm{~mm}$ sieved soil in each pot. As a soil amendment, biochar can greatly influence various soil properties and processes (Lehmann and Joseph, 2009). The presence of biochar in the soil can improve soil chemical (e.g., pH, CEC) (Liang et al., 2006) and physical properties (e.g., soil water retention, hydraulic conductivity) (Major et al., 2009). Total N concentration in biochar from wheat straw is $4.60 \mathrm{~g} \mathrm{~kg}^{-1}$ based on laboratory results (Singh et al., 2017). The main physical and chemical properties of the wheat straw and the biochar used in the experiment are reported in Table 2.

\section{Soil sampling and analysis}

Before trial started, a representative soil sample $(1 \mathrm{~kg})$ was used to determine physical and chemical characteristics. Soil texture was determined by the pipette gravimetric method. $\mathrm{pH}$ was measured on 1:2.5 (w/s) aqueous soil extract. Humidity (W) was established by weighing the soil before and after drying in an oven at $105^{\circ} \mathrm{C}$ (ISO 11465 ). Total $\mathrm{N}$ was determined after digestion with
$\mathrm{H}_{2} \mathrm{SO}_{4}$ and $\mathrm{H}_{2} \mathrm{O}_{2}$ according to Kjeldahl method (DIN EN 16169, 2012). Total $P$ was measured according to the ascorbic acid molybdenum blue method (DIN EN 16169, 2012; Murphy and Riley, 1962). $\mathrm{NO}_{3}{ }^{-}-\mathrm{N}$ was determined within $24 \mathrm{~h}$, by using $\mathrm{KCl} 2 \mathrm{M}$ extraction followed by measurement with spectrophotometer, according to Keeney and Nelson (1982). Organic carbon was measured with the Walkley and Black method (1934), after oxidation of organic matter by potassium dicromate $\left(\mathrm{K}_{2} \mathrm{Cr}_{2} \mathrm{O}_{7}\right)$ in mixture with $\mathrm{H}_{2} \mathrm{SO}_{4}$, followed by tritation with ammonium ferrous sulphate $\left[\mathrm{Fe}\left(\mathrm{NH}_{4}\right)_{2}\left(\mathrm{SO}_{4}\right)_{2} \times 6 \mathrm{H}_{2} \mathrm{O}\right]$. The micronutrients, such as $\mathrm{Mg}, \mathrm{Fe}, \mathrm{K}$, $\mathrm{Ca}$, were analysed with a Flame Atomic Absorption Spectrometer type AA350, according to the Method 3051A (2007).

During the three months of experiment, soil samples were taken three times, at interval of one month, from the pots. They were collected with a sterile probe by plunging in pot $0-10 \mathrm{~cm}$ depth and extracting the probe carefully to avoid disturbing the soil structure in the pot. The empty space created after the sampling was filled with a clean plastic pipe to precisely maintain the soil structure. Soil samples were analysed for $\mathrm{NO}_{3}{ }^{-}-\mathrm{N}$ and Total $\mathrm{N}$. $\mathrm{NO}_{3}{ }^{-} \mathrm{N}$-was measured immediately after the sampling. For Total $\mathrm{N}$ measurement, the soil samples were air dried, sieved at $2 \mathrm{~mm}$, well mixed and then analysed.

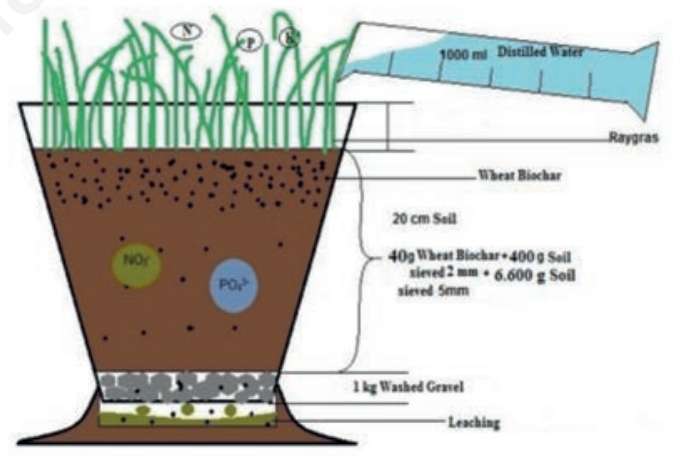

Figure 2. Pot experiment design.

Table 2. Main physical and chemical parameters measured on wheat straw and biochar from wheat straw used in the experiment.

\begin{tabular}{lcc} 
Parameter & \multicolumn{2}{c}{ Amendment type } \\
Wiochar & Wheat straw \\
$\mathrm{pH}$ & 10.51 & - \\
Organic matter $\left(\mathrm{g} \mathrm{kg}^{-1}\right)$ & - & 669.15 \\
\hline Total C (\%) & 48.53 & 9.83 \\
Total N (\%) & 0.46 & 0.37 \\
\hline Total P (\%) & 0.11 & 37.81 \\
Total K (\%) & 5.24 & - \\
\hline Specific surface area $\left(\mathrm{m}^{2} \mathrm{~g}^{-1}\right)$ & 4.81 & - \\
Pore volume $\left(\mathrm{cm}^{3} \mathrm{~g}^{-1}\right)$ & 0.0051 & - \\
\hline Pore width $(\mathrm{nm})$ & 5.00 & - \\
\hline
\end{tabular}




\section{Plant sampling and analysis}

One month after planting, the plants were cut at $2-3 \mathrm{~cm}$ from the soil surface of each pot and weighed. After cutting, the plants were uniformly washed with distilled water to eliminate adhering substances and dried in an oven at $60^{\circ} \mathrm{C}$, till constant weight. Then they were grounded in a Wiley mill and analysed for Total N, after digestion with Kjeldhal method (Taylor and Francis Group, 1998). After one and two months from the first plant sampling, the second and the third cuts were respectively realised for all the treatments.

\section{Leaching water sampling and analysis}

After each of the three plant cuts, the soils of each pot were subjected to leaching. This was achieved by filling the pots of each treatment with $1000 \mathrm{~mL}$ of distilled water by a very slow process of water application (Figure 3) and expecting the irrigation finished in order to collect the drainage water. The amount of water used for leaching corresponds to a rainfall of almost $26 \mathrm{~mm}$, which happens frequently in the Skodra region. A total of three leaching cycles were applied to the pots, following the same procedure. From each of the seven treatments, a leachate of $450 \mathrm{~mL}$ on average was collected. The percolate of each pot was stored in dark plastic bottles in refrigerator at a temperature of $4{ }^{\circ} \mathrm{C}$ and $\mathrm{NO}_{3}{ }^{-}-\mathrm{N}$ was determined within $24 \mathrm{~h}$, according to UNEP/MAP/MED POL (2005).

\section{Statistical analysis}

The data collected during the three months of experimental trial were statistically analysed by ANOVA (two tailed). Since the data did not show a normal distribution, the statistically significant differences between means were tested using the nonparametric Kruskal Wallis test $(\mathrm{P}<0.05)$.

\section{Results and discussion}

\section{Soil properties}

The results of physical analysis (Table 3) showed that the soil used in the experiment had a sandy loam texture (United States Department of Agriculture classification), with $43 \%$ of sand. The chemical analysis showed a moderate amount of macro and microelements in soil composition (Table 3 ).

\section{Leached $\mathrm{NO}_{3}^{-}-\mathrm{N}$}

The values obtained based on $\mathrm{NO}_{3}{ }^{-}-\mathrm{N}$ concentration in leachate in $\mathrm{mg} \mathrm{L}^{-1}$ and the amount of leaching water in $\mathrm{mL}$ served to calculate the $\mathrm{NO}_{3}{ }^{-}-\mathrm{N}$ in $\mathrm{mg} \mathrm{kg}^{-1}$ soil leached from each treatment after each plant cut and the $\mathrm{NO}_{3}{ }^{-}-\mathrm{N}$ in $\mathrm{kg} \mathrm{N} \mathrm{Na}^{-1}$ leached from the soil surface to the soil depth of $30 \mathrm{~cm}$ (Table 4).

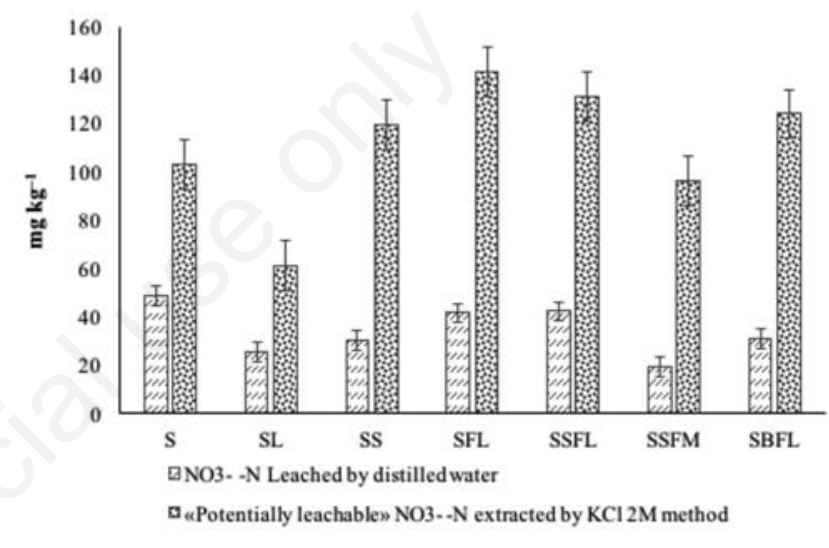

Figure 3. Comparison between the corresponding values of $\mathrm{NO}_{3}{ }^{-}-\mathrm{N}$ according to leaching with distilled water and extraction with $2 \mathrm{M} \mathrm{KCl}$.

Table 3. Main physical and chemical characteristics of the soil used in the experiment.

\begin{tabular}{|c|c|c|c|c|c|c|c|c|c|c|c|c|c|}
\hline \multirow{2}{*}{ Soil type } & \multicolumn{5}{|c|}{ Physical characteristics } & \multicolumn{8}{|c|}{ Chemical characteristics } \\
\hline & $\begin{array}{c}\text { Sandy } \\
(\%)\end{array}$ & $\begin{array}{l}\text { Silty } \\
(\%)\end{array}$ & $\begin{array}{l}\text { Clay } \\
(\%)\end{array}$ & $\begin{array}{l}\text { W } \\
(\%)\end{array}$ & $\mathrm{pH}$ & $\begin{array}{c}\mathrm{NO}_{3}{ }^{-}-\mathrm{N} \\
\left(\mathrm{mg} \mathrm{kg}^{-1}\right)\end{array}$ & $\begin{array}{l}\text { Total-N } \\
\left(\mathrm{g} \mathrm{kg}^{-1}\right)\end{array}$ & $\begin{array}{c}\text { Total-P } \\
\left(\mathrm{g} \mathrm{kg}^{-1}\right)\end{array}$ & $\begin{array}{c}\text { Organic-C } \\
\left(\mathrm{g} \mathrm{kg}^{-1}\right)\end{array}$ & $\begin{array}{c}\mathrm{Mg} \\
\left(\mathrm{g} \mathrm{kg}^{-1}\right)\end{array}$ & $\begin{array}{c}\mathrm{Fe} \\
\left(\mathrm{g} \mathrm{kg}^{-1}\right)\end{array}$ & $\begin{array}{c}\mathrm{K} \\
\left(\mathrm{g} \mathrm{kg}^{-1}\right)\end{array}$ & $\begin{array}{c}\mathrm{Ca} \\
\left(\mathrm{g} \mathrm{kg}^{-1}\right)\end{array}$ \\
\hline SLS & 43.19 & 33.67 & 23.14 & 5.08 & 8.00 & 166.16 & 1.560 & 0.67 & 19.47 & 17.29 & 15.65 & 4.69 & 0.80 \\
\hline
\end{tabular}

SLS, sandy loam soil.

Table 4. $\mathrm{NO}_{3}{ }^{-}-\mathrm{N}$ leached from the soil, as determined by soil leaching with distilled water and expressed as average value of four replications.

\begin{tabular}{|c|c|c|c|c|c|c|c|c|}
\hline \multirow[t]{2}{*}{ Treatment } & \multicolumn{3}{|c|}{ Concentration of $\mathrm{NO}_{3}{ }^{-}-\mathrm{N}$ in leachate } & \multicolumn{4}{|c|}{ Leached $\mathrm{NO}_{3}{ }^{-}-\mathrm{N}$} & \multirow{2}{*}{$\begin{array}{c}\mathrm{NO}_{3}{ }^{-}-\mathrm{N} \text { leached from } \\
\text { the } 0-30 \mathrm{~cm} \text { soil layer } \\
\qquad \mathrm{kg} \mathrm{N} \mathrm{ha}^{-1}\end{array}$} \\
\hline & $1^{\text {st }}$ cut & $\begin{array}{l}2^{\text {nd }} \text { cut } \\
\mathrm{mg} \mathrm{L}^{-1}\end{array}$ & $3^{\text {rd }}$ cut & $1^{\text {st }}$ cut & $\begin{array}{c}2^{\text {nd }} \text { cut } \\
\mathrm{mg} \mathrm{kg}^{-1} \text { soil }\end{array}$ & $3^{\text {rd }}$ cut & $\begin{array}{c}\text { Amount } \\
\mathrm{mg} \mathrm{kg}^{-1} \text { soil }\end{array}$ & \\
\hline $\mathrm{S}$ & $189.58 \pm 41.41^{\mathrm{a}}$ & $293.15 \pm 46.81^{\mathrm{a}}$ & $275.27 \pm 40.72^{b}$ & 12.19 & 18.67 & 17.62 & 48.48 & 163.77 \\
\hline SL & $139.25 \pm 25.70^{\mathrm{b}}$ & $134.81 \pm 16.35^{b}$ & $133.79 \pm 19.12^{c}$ & 8.95 & 8.85 & 7.70 & 25.50 & 106.04 \\
\hline SS & $63.82 \pm 16.82^{\mathrm{c}}$ & $134.79 \pm 53.24^{b}$ & $272.75 \pm 50.25^{b}$ & 4.04 & 8.66 & 17.53 & 30.24 & 108.85 \\
\hline SFL & $79.77 \pm 16.49^{\mathrm{d}}$ & $241.92 \pm 20.66^{c}$ & $325.28 \pm 25.8^{\mathrm{a}}$ & 5.13 & 15.55 & 20.91 & 41.59 & 149.73 \\
\hline SSFL & $91.00 \pm 15.71^{\mathrm{e}}$ & $266.80 \pm 32.7^{\mathrm{c}}$ & $300.00 \pm 40.04^{\mathrm{ab}}$ & 5.85 & 17.15 & 19.29 & 42.29 & 156.47 \\
\hline SSFM & $96.72 \pm 29.82^{b}$ & $95.16 \pm 28.85^{\mathrm{d}}$ & $105.20 \pm 37.59^{c}$ & 6.22 & 6.14 & 6.76 & 19.12 & 50.83 \\
\hline SBFL & $70.49 \pm 13.26 \mathrm{~d}^{\mathrm{c}}$ & $64.26 \pm 8.27^{\mathrm{e}}$ & $112.10 \pm 4.16^{\mathrm{c}}$ & 8.81 & 8.03 & 14.01 & 30.84 & 111.04 \\
\hline
\end{tabular}

a-e Means followed by same letters in each column are not different (significant differences at $\mathrm{P}<0.05$ ). 
$\mathrm{NO}_{3}{ }^{-}-\mathrm{N}$ concentrations in leachate expressed in $\mathrm{mg} \mathrm{L}^{-1}$ showed an increase from the $1^{\text {st }}$ cut to the $3^{\text {rd }}$ cut in all the considered treatments, except for SL treatment where the $\mathrm{NO}_{3}{ }^{-}-\mathrm{N}$ values were pratically constant. In the third cut, maize treatment (SSFM) showed the lowest $\mathrm{NO}_{3}{ }^{-}-\mathrm{N}$ concentration $\left(<110 \mathrm{mg} \mathrm{L}^{-1}\right)$. The lower nitrate-nitrogen concentration values of the $1^{\text {st }}$ cut were observed in SS and SBLF treatments, lower or near to $70 \mathrm{mg} \mathrm{L}^{-1}$, while the highest value was obtained in control (S) $\left(189.58 \mathrm{mg} \mathrm{L}^{-1}\right)$. In the $2^{\text {nd }}$ cut, the higher $\mathrm{NO}_{3}{ }^{-}-\mathrm{N}$ concentrations were found in $\mathrm{S}$, SSFL and SFL, with $293.15 \pm 46.81 ; 266.8 \pm 32.7$ and $241.92 \pm 20.66$ $\mathrm{mg} \mathrm{L}^{-1}$, respectively. Particularly, in SFL and SSFL $\mathrm{NO}_{3}{ }^{-}-\mathrm{N}$ values were about three times higher compared with the values recorded after the $1^{\text {st }}$ cut in the same treatments. For the control (S) the $\mathrm{NO}_{3}$ $-\mathrm{N}$ value after the $2^{\text {nd }}$ cut was $55 \%$ higher than after the $1^{\text {st }}$ one. In SSFM, the $\mathrm{NO}_{3}{ }^{-}-\mathrm{N}$ concentration was about $9 \%$ lower than the $1^{\text {st }}$ cut. The lowest $\mathrm{NO}_{3}{ }^{-}-\mathrm{N}$ value of all the other treatments after the $2^{\text {nd }}$ cut was found in SBFL $\left(64.26 \pm 8.27 \mathrm{mg} \mathrm{L}^{-1}\right)$. The $\mathrm{NO}_{3}{ }^{-}-\mathrm{N}$ values observed after the $2^{\text {nd }}$ and the $3^{\text {rd }}$ cut were not different for $\mathrm{S}$, $\mathrm{SL}$, and SSFL treatments; while $\mathrm{NO}_{3}{ }^{-}-\mathrm{N}$ values after the $3^{\text {rd }}$ cut were two times higher than the $2^{\text {nd }}$ in the case of SS, $80 \%$ higher in the case of SBFL and 15\% higher in the case of SSFM.

The comparison between $\mathrm{NO}_{3}{ }^{-}-\mathrm{N}$ values observed in $\mathrm{S}$ and $\mathrm{SL}$ both after $2^{\text {nd }}$ and $3^{\text {th }}$ cut showed that in the absence of the root system of plants $\mathrm{NO}_{3}{ }^{-}-\mathrm{N}$ leached from bare soil was twice higher than the soil cultivated with ryegrass, confirming once again the undisputable effect of nitrates uptake by plant. The comparison between $\mathrm{NO}_{3}{ }^{-}-\mathrm{N}$ leached in the treatments with biochar and wheat straw, in presence of ryegrass and NPK fertilisation (SBFL vs SSFL) showed the retention effect of biochar, both during the $3^{\text {rd }}$ and the $2^{\text {nd }}$ cut (112 vs 300 and 64 vs $267 \mathrm{mg} \mathrm{L}^{-1}$, respectively). When maize was cultivated in presence of wheat straw amendment and NPK fertilisation, an intensive nitrate retention system was defined in all the three cuts compared to all the other treatments, due to the fact that the root system acts as a sink.

Total amount of leached $\mathrm{NO}_{3}{ }^{-}-\mathrm{N}$ in $\mathrm{mg} \mathrm{kg}^{-1}$ soil (Table 4) followed the same trend as in the case of $\mathrm{NO}_{3}{ }^{-} \mathrm{N}$ concentration in leachate. In general, higher values were found in the $3^{\text {rd }}$ cut compared to the $2^{\text {nd }}$ one for all the treatments, except for SL and SSFM where leached $\mathrm{NO}_{3}{ }^{-}-\mathrm{N}$ were approximately $7 \mathrm{mg} \mathrm{kg}^{-1}$ soil. The same values expressed in $\mathrm{kg} \mathrm{N} \mathrm{ha}^{-1}$ resulted in the following ranking among the different treatments: $S>S S F L \geq S F L>S B F L \geq$ $\mathrm{SS} \geq \mathrm{SL}>\mathrm{SSFM}$. From the results of this experiment, significant findings could be observed: i) ryegrass and wheat straw, with or without NPK, had the same effect on $\mathrm{NO}_{3}{ }^{-}-\mathrm{N}$ retention; ii) SL and SS treatments showed a similar amount of $\mathrm{NO}_{3}{ }^{-} \mathrm{N}$ leached from
$0.30 \mathrm{~cm}$ soil depth, with a reduction of about $35 \%$ compared to the control (S); iii) biochar, in presence of NPK fertilisation and ryegrass was more effective in reducing $\mathrm{NO}_{3}{ }^{-} \mathrm{N}$ leaching from 0.30 soil depth than SFL and SSFL treatments. Indeed, in SBLF, $\mathrm{NO}_{3}^{-}-$ $\mathrm{N}$ leached was lower of about $27 \%$ than SFL (111.04 vs. $156.47 \mathrm{~kg}$ $\mathrm{N} \mathrm{ha}^{-1}$ ) and $26 \%$ than SSFL (111.04 vs $\left.149.73 \mathrm{~kg} \mathrm{~N} \mathrm{ha}^{-1}\right)$; iv) the effect of maize root system (SSFM) on $\mathrm{NO}_{3}{ }^{-}-\mathrm{N}$ retention was two and three times higher compared to biochar and heat straw (50.83 vs 111.04 and $\left.149.73 \mathrm{~kg} \mathrm{ha}^{-1} \mathrm{NO}_{3}{ }^{-}-\mathrm{N}\right)$, respectively.

\section{Potentially leachable (PL) $\mathrm{NO}_{3}{ }^{-}-\mathrm{N}$}

One of the objectives of the study was to determine the $\mathrm{NO}_{3}^{-}$$\mathrm{N}$ potentially available to be leached $(P L)$ from soil using $2 M \mathrm{KCl}$ extraction (Bremner, 1965; McTaggart and Smith, 1993). This extraction method was applied to the soil of each experimental treatment after each of the three plant cuts. The obtained results (Table 5) showed that $P L \mathrm{NO}_{3}{ }^{-}-\mathrm{N}$ was higher compared to $\mathrm{NO}_{3}{ }^{-}-\mathrm{N}$ leached by distilled water, and this because the different extraction methods applied (leaching with 11 of distilled water vs. extraction with $200 \mathrm{~mL} 2 M \mathrm{KCl}$ diluted in $100 \mathrm{~g}$ of soil). The value of $P L$ $\mathrm{NO}_{3}{ }^{-}-\mathrm{N}$ expressed in $\mathrm{mg} \mathrm{kg}^{-1}$ soil was high in all the treatments (Table 5). $P L \mathrm{NO}_{3}{ }^{-}-\mathrm{N}$ values showed different patterns: a decrease of $P L \mathrm{NO}_{3}{ }^{-}-\mathrm{N}$ from the $1^{\text {st }}$ to the $3^{\text {rd }}$ cut was registered for the SSFM treatment; highest values after the $2^{\text {nd }}$ cut compared to the $1^{\text {st }}$ and the $3^{\text {rd }}$ cut for SL and SSFL treatments; increasing values from the $1^{\text {st }}$ to the $3^{\text {rd }}$ cut for all the other treatments.

The cumulative $P L \mathrm{NO}_{3}{ }^{-}-\mathrm{N}$ values were from 60.76 (SL) to $141.10 \mathrm{mg} \mathrm{kg}^{-1}$ soil (SFL). $P L \mathrm{NO}_{3}{ }^{-}-\mathrm{N}$ was $40 \%$ lower in SL compared to $\mathrm{S}\left(60.76\right.$ vs $\left.102.67 \mathrm{~kg} \mathrm{~N} \mathrm{ha}^{-1}\right)$. On average, the $P L \mathrm{NO}_{3}^{-}-$ $\mathrm{N}$ values founded in straw treatments (SS and SSFL) were higher compared to the bare soil of about $22 \%$. We presume that these differences come as a result of straw mineralisation process occurred during the 14 weaks of greenhouse conditions. In SS treatment, the sharp increase of $P L \mathrm{NO}_{3}{ }^{-}-\mathrm{N}$ values observed from after the $1^{\text {st }}$ to the $3^{\text {rd }}$ cut should be due to the progressive mineralisation process of straw $\left(7.22,44.77\right.$ and $67.15 \mathrm{mg} \mathrm{kg}^{-1}$ soil per $1^{\text {st }}, 2^{\text {nd }}$ and $3^{\text {rd }}$ cuts, respectively). As for $\mathrm{NO}_{3}^{-}-\mathrm{N}$ leached by distilled water also for $P L \mathrm{NO}_{3}{ }^{-} \mathrm{N}$ the cumulative values were higher in SFL and SSFL (141.1 and $130.9 \mathrm{mg} \mathrm{kg}^{-1}$ soil, respectively). For SBFL the cumulative $P L \mathrm{NO}_{3}{ }^{-} \mathrm{N}$ values were lower compared to $\mathrm{SFL}$ and SSFL. The effect of biochar on $\mathrm{NO}_{3}^{-}-\mathrm{N}$ retention, as also discussed in previous studies (Libutti et al., 2016), should be due to the improved cation exchange capacity (Glaser et al., 2002; Cornelissen et al., 2013) and improvement of soil physical and hydraulic properties (Bruun et al., 2014).

Table 5. Potentially leachable $\mathrm{NO}_{3}{ }^{-}-\mathrm{N}\left(P L \mathrm{NO}_{3}{ }^{-}-\mathrm{N}\right)$ in the soil, as determined by soil extraction with $2 \mathrm{M}$ KCl and expressed as average value of four replications.

\begin{tabular}{|c|c|c|c|c|c|c|}
\hline \multirow[t]{2}{*}{ Treatment } & \multicolumn{3}{|c|}{$P L \mathrm{NO}_{3}{ }^{-}-\mathrm{N}$ (mg kg-1 soil) } & \multicolumn{2}{|c|}{ Amount } & \multirow{2}{*}{$\begin{array}{c}P L \mathrm{NO}_{3}-\mathrm{-N} / \text { Total }-\mathrm{N} \\
(\%)\end{array}$} \\
\hline & $1^{\text {st }}$ cut & $2^{\text {nd }}$ cut & $3^{\text {rd }}$ cut & mg kg-1 soil & $\mathrm{kg} \mathrm{N} \mathrm{ha-1}^{-1}$ & \\
\hline S & $24.09 \pm 0.78^{b}$ & $28.24 \pm 1.84^{\mathrm{bc}}$ & $50.34 \pm 1.33^{b}$ & 102.67 & 369.60 & 6.58 \\
\hline SL & $17.70 \pm 0.33^{\mathrm{c}}$ & $24.98 \pm 2.13^{\mathrm{c}}$ & $18.06 \pm 0.99 c$ & 60.76 & 218.75 & 3.89 \\
\hline SS & $7.22 \pm 0.43^{\mathrm{d}}$ & $44.77 \pm 4.36^{\mathrm{b}}$ & $67.15 \pm 0.99^{\mathrm{a}}$ & 119.14 & 428.89 & 7.64 \\
\hline SFL & $22.32 \pm 3.21^{\mathrm{bc}}$ & $59.29 \pm 3.96^{\mathrm{ab}}$ & $59.49 \pm 1.48^{\mathrm{ab}}$ & 141.10 & 507.98 & 9.04 \\
\hline SSFL & $24.22 \pm 3.41^{b}$ & $64.80 \pm 2.58^{\mathrm{a}}$ & $41.86 \pm 1.87^{\mathrm{bc}}$ & 130.87 & 471.15 & 8.93 \\
\hline SSFM & $45.47 \pm 1.93^{\mathrm{a}}$ & $30.10 \pm 1.31^{\mathrm{bc}}$ & $20.09 \pm 2.25^{c}$ & 95.70 & 344.53 & 4.46 \\
\hline SBFL & $22.20 \pm 4.50^{\mathrm{bc}}$ & $45.34 \pm 2.45 \mathrm{~b}$ & $56.22 \pm 1.36^{\mathrm{ab}}$ & 123.77 & 445.56 & 7.93 \\
\hline
\end{tabular}

a-dMeans followed by same letters in each column are not different (significant differences at $\mathrm{P}<0.05$ ). 
The amount of $P L \mathrm{NO}_{3}{ }^{-}-\mathrm{N}$ calculated per hectar of soil (Table 5) was quite high in all the treatments, showing a range from 219 (SL) to $508 \mathrm{~kg} \mathrm{ha}^{-1}$ (SFL). Expressed as percentage of the total $\mathrm{N}$ in the bare soil before trial started (1560 $\mathrm{mg} \mathrm{kg}^{-1}$ soil; Table 3), $P L$ $\mathrm{NO}_{3}{ }^{-}-\mathrm{N}$ showed a high variability; from $3.89 \%$ in treatment with ryegrass without NPK (SL) and up to $9.04 \%$ in treatment with ryegrass and with NPK (SFL). If we compare the first treatment (S) and the second one (SL), we can notice that the presence of ryegrass has contributed to decrease by half the amount of $P L \mathrm{NO}_{3}{ }^{-}$$\mathrm{N}$. In the treatments where wheat straw, mineral nitrogen fertiliser and ryegrass were applied (SFL and SSFL), the percentage of mineralised nitrogen was higher than in the case of bare soil. Grazhdani et al., (1996) in a similar type of soil (total nitrogen content of $1870 \mathrm{mg} \mathrm{kg}^{-1}$ soil and loamy sandy soil texture) measured in an incubation test experiment of 33 weeks the $N$ potentially mineralisable pool and founded it was $13 \%$ of the total organic nitrogen stock, or twice the nitrogen extracted on bare soils.

The cumulative $\mathrm{NO}_{3}{ }^{-}-\mathrm{N}$ values by the two methods (extraction with $2 M \mathrm{KCl}$ and leaching with distilled water) are showed in Figure 3. In the first two treatments (S and SL, respectively), the ratio between $P L \mathrm{NO}_{3}{ }^{-}-\mathrm{N}$ and leached $\mathrm{NO}_{3}{ }^{-}-\mathrm{N}$ was close to 2 (2.1 and 2.3 for $\mathrm{S}$ and $\mathrm{SL}$, respectively). The $\mathrm{KCl}$ extraction method extracted at least the double amount of nitrate compared to distilled water in all the treatments. In SS treatment, this ratio was about four times higher due to enhanced microbial activity from the presence of straw that should has also increased the mineralisation of organic $\mathrm{N}$ in the soil as well as organic $\mathrm{N}$ in the straw. In fertilised and wheat straw amended treatments (SFL and SSFL) this ratio was higher than 3 . The presence of biochar, due to its retention capacity of mineral $\mathrm{N}$, increased the ratio between $P L$ $\mathrm{NO}_{3}{ }^{-}-\mathrm{N}$ and leached $\mathrm{NO}_{3}{ }^{-}-\mathrm{N}$ to 4 . The maximum value of the ratio was observed in SFLM, although the $P \mathrm{~L} \mathrm{NO}_{3}{ }^{-}-\mathrm{N}$ and $\mathrm{NO}_{3}{ }^{-}-\mathrm{N}$ values were relatively low ( 95.7 and $19.12 \mathrm{mg} \mathrm{kg}^{-1}$ soil, respectively) compared with the other fertilised and organic amended treatments, due to the important role of maize root system in $\mathrm{N}$ uptake. Mineralisation of the organic amendments and fertiliser used were sharply increased by a more intensive microbial activity, enhanced from the presence of the root system.

\section{Nitrogen plant uptake and apparent nitrogen use efficiency}

The nitrogen amounts absorbed by plant showed differences between cuts and treatments (Table 6 ). In the $1^{\text {st }}$ cut, $\mathrm{N}$ uptake values expressed in mg pot ${ }^{-1}$ were higher than the other two cuts and varied from 40 in SL up to 187 in SSFM. The other three treatments did not show statistically significant differences among them. In the $3^{\text {rd }}$ cut for all the treatments with fertiliser and/or organic amendments, the values of $\mathrm{N}$ uptake were lower or at least equal than the previous two cuts. As expected, in all the three cuts, the values of $\mathrm{N}$ uptake were lower in non-fertilised treatment compared to the nitrogen fertiliser treatments. There were no differences in $\mathrm{N}$ uptake values between SSFL and SBFL (339.8 vs $350.4 \mathrm{mg} \mathrm{pot}^{-1}$, respectively), and in the presence of maize this value was higher (406.5 $\left.\mathrm{mg} \mathrm{pot}^{-1}\right)$ than the ryegrass.

The total $\mathrm{N}$ uptake values in $\mathrm{mg} \mathrm{kg}^{-1}$ soil for the three cuts, ranged from 18.16 in non-fertilised treatment (SL) to 58.06 for SSFM. In SSFL, N uptake value was lower than SFL, showing an inhibitory effect of organic substrate in absorbing $\mathrm{N}$ from fertiliser. The organic substrates (SSFL and SBFL) effect in absorbing nitrogen from the soil was comparable. This appears also in the values of $\mathrm{N}$ uptake expressed in $\mathrm{mg} \mathrm{kg}^{-1}$ soil and $\mathrm{kg} \mathrm{N} \mathrm{ha}^{-1}$, and nitrogen use efficiency. Maize (SSFM treatment) showed higher $\mathrm{N}$ uptake ability and NUE compared to ryegrass (SL, SFl, SSFl and SBFL treatments) ( $\mathrm{N}$ total uptake and NUE were $209 \mathrm{~kg} \mathrm{~N} \mathrm{ha}^{-1}$ and $47.8 \%$, respectively). The lowest value of NUE was observed in treatment with nitrogen fertilised and wheat straw (SSFL, close to $36.5 \%$ ) while for biochar treatment NUE was slightly higher but not significantly different $(\mathrm{P}<0.01)(36.46$ vs $38.27 \%$, respectively). This result highlights the effectiveness of biochar soil amendment not only in nitrate retention but also in plant nutrition (Kammann et al., 2011).

\section{Conclusions}

A three months pot experiment, carried out under greenhouse conditions with Lolium multiflorum L. and Zea mays L., was aimed at evaluate the effect of wheat straw and biochar amendment on nitrate retention of a sandy loam soil, under the same rate of NPK fertiliser.

The main findings observed in the course of the study are: i) biochar reduced of about $26 \%$ the amount of $\mathrm{NO}_{3}{ }^{-}-\mathrm{N}$ leached from $0.30 \mathrm{~cm}$ soil depth compared to wheat straw, in presence of NPK fertilisation and ryegrass; ii) the effect of maize root system on $\mathrm{NO}_{3}{ }^{-}-\mathrm{N}$ leaching reduction was two and three times higher compared to biochar and wheat straw, respectively. Furthemore, the amount of $\mathrm{PL} \mathrm{NO}_{3}{ }^{-}-\mathrm{N}$ calculated per hectar of soil was higher in the treatments where wheat straw, mineral nitrogen fertiliser and ryegrass were applied. To the amount of extracted nitrogen contributed also nitrogen added by wheat straw mineralisation and fertiliser. Results from the study indicated a mitigating action of biochar on leaching of $\mathrm{NO}_{3}{ }^{-}-\mathrm{N}$. In presence of plant roots and fertilisation, this effect was higher than wheat straw. However, being a short-term experiment, future research needs to test the same biochar and wheat straw application on soil in long-term experimental trials under field conditions.

Table 6. Nitrogen plant uptake and nitrogen use efficiency.

\begin{tabular}{|c|c|c|c|c|c|c|c|}
\hline \multirow[t]{2}{*}{ Treatment } & \multicolumn{4}{|c|}{ N uptake (mg pot ${ }^{-1}$ ) } & \multicolumn{2}{|c|}{ Total N uptake } & \multirow{2}{*}{$\begin{array}{l}\text { Nitrogen use } \\
\text { efficiency (\%) }\end{array}$} \\
\hline & $1^{\text {st }}$ cut & $2^{\text {nd }}$ cut & $3^{\text {rd }}$ cut & Amount & $\mathrm{mg} \mathrm{kg}^{-1}$ soil & $\mathbf{k g ~ N h a ^ { - 1 }}$ & \\
\hline SL & $39.99 \pm 5.55^{\mathrm{c}}$ & $42.12 \pm 2.46^{\mathrm{c}}$ & $45.21 \pm 4.32^{c}$ & 127.32 & 18.16 & 65.37 & 0 \\
\hline SFL & $161.8 \pm 6.34^{b}$ & $127.5 \pm 6.87^{\mathrm{a}}$ & $97.3 \pm 10.63^{\mathrm{a}}$ & 386.6 & 55.23 & 198.82 & 44.48 \\
\hline SSFL & $152.5 \pm 6.81^{\mathrm{ab}}$ & $92.7 \pm 11.79^{b}$ & $94.6 \pm 14.16^{\mathrm{ab}}$ & 339.8 & 48.54 & 174.75 & 36.46 \\
\hline SSFM & $187.1 \pm 1.76^{\mathrm{a}}$ & $127.9 \pm 3.42^{\mathrm{a}}$ & $91.5 \pm 16.44^{\mathrm{ab}}$ & 406.5 & 58.06 & 209.01 & 47.87 \\
\hline SBFL & $154.3 \pm 5.23^{\mathrm{ab}}$ & $107.2 \pm 17.34^{\mathrm{ab}}$ & $88.9 \pm 7.76^{\mathrm{b}}$ & 350.4 & 50.04 & 180.21 & 38.27 \\
\hline
\end{tabular}

${ }^{\mathrm{a}-\mathrm{c}}$ Means followed by same letters in each column are not different (significant differences at $\mathrm{P}<0.05$ ). 


\section{References}

Billen G, Garnier J, 1999. Nitrogen transfers through the Seine drainage network: a budget based on the application of the Riverstrahler model. Hydrobiologia 410:139-50.

Birgand F, Skaggs RW, Cheischer GM, Gillliam JW, 2007. Nitrogen removal in streams of agricultural catchments - a literature review. Crit. Rev. Env. Sci. Tec. 37:381-487.

Bradley A, Larson RA, Runge T, 2015. Effect of wood biochar in manure-applied sand columns on leachate quality. J. Environ. Qual. 44:1720-8.

Bremner JM, 1996. Nitrogen-total. In: D.L. Sparks, A.L. Page, C.T. Johnston, M.E. Summ (Eds). Methods of soil analysis, Part 3. Chemical methods. SSSA Book Ser. No. 5. SSSA, Madison, WI, USA, pp 1058-1121.

Bruun EW, Petersen CT, Hansen E, Holm JK, Hauggaard-Nielsen H, 2014. Biochar amendment to coarse sandy subsoil improves root growth and increases water retention. Soil Use Manage. 30:109-11.

Buecker J, Kloss S, Wimmer B, Rempt F, Zehetner F, Soja G, 2016. Leachate composition of temperate agricultural soils in response to biochar application. Water Air Soil Poll. 227:49.

Carpenter SR, Caraco NF, Correl DL, Howarth RW, Sharpley AN, Smith VH, 1998. Nonpoint pollution of surface waters with phosphorus and nitrogen. Ecol. Appl. 8:559-68.

Cheng Y, Cai Z, Chang SX, Wang J, Zhang J, 2012. Wheat straw and its biochar have contrasting effects on inorganic $\mathrm{N}$ retention and $\mathrm{N}_{2} \mathrm{O}$ production in a cultivated Black Chernozem. Biol. Fert. Soils 48:941-6.

Cornelissen GM, Martinsen V, Shitumbanuma V, Alling V, Breedveld GD, Rutherford DW, Sparrevik M, Hale S, Obia A, Mulder J, 2013. Biochar effect on maize yield and soil characteristics in five conservation farming sites in Zambia Agronomy 3:256-74.

Cullaj A, Hasko A, Miho A, Schanz F , Brandle H, Bachofenf R, 2005. The quality of Albanian natural waters and the human impact. Environ. Int. 31:133-46.

Delgado JA, 2002. Quantifying the loss mechanisms of nitrogen. J. Soil Water Conserv. 57:389-98.

Dhora D, Bekteshi A, Rakai M, 2012. Consideration on the eutrophication in the Lake of Shkodra. International Conference, 16-17 November 2012, Shkoder, Albania.

Dhora D, 2016. Liqeni i Shkodrës. Biblioteka Shkodër. Available from: http://www.bibliotekashkoder.com/doc/liqeni_shkodres 2016.pdf

DIN EN 16169, 2012. Sludge, treated biowaste and soil Determination of Kjeldahl nitrogen.

Döring TF, Brandt M, Heß J, Finckh MR, Saucke H, 2005. Effects of straw mulch on soil nitrate dynamics, weeds, yield and soil erosion in organically grown potatoes. Field Crop Res. 94:238-49.

Durand P, Breuer L, Johnes PJ, Billen G, Butturini A, Pinay G, van Grinsven H, Garnier J, Rivett M, Reay D. S, Curtis C, Siemens J, Maberly S, Kaste O, Humborg C, Loeb R, de Klein J, Hejzlar J, Skoulikidis N, Kortelainen P, Lepisto A, Wright R, 2011. Nitrogen processes in aquatic ecosystems. The European Nitrogen Assessment. European Union: Published by Cambridge University Press.

EEA, 2015. The European Environment - State and Outlook 2015: synthesis report, European Environment Agency, Copenhagen. Available from: http://www.eea.europa.eu/soer
EEA, 1995. Europe's Environment. The Dobris Assessment. No 1/1995. European Environment Agency. Available from: https://www.eea.europa.eu/publications/92-827-5122-8

Garg S, Bahl G, 2008. Phosphorus availability to maize as influenced by organic manures and fertilizer $\mathrm{P}$ associated phosphatase activity in soils. Bioresour. Technol. 99:5773-7.

Glaser B, Lehmann J, Wolfgang Z, 2002. Ameliorating physical and chemical properties of highly weathered soils in the tropics with charcoal - a review. Biol. Fertil. Soils 35:219-30.

Grazhdani S, Jacquin F, Sulçe S, 1996. Effect of subsurface drainage on nutrient pollution of surface water in south eastern Albania.. Sci. Total Environ. 191:15-21.

Haider G, Steffens D, Moser G, Müller C, Kammann CI, 2017. Biochar reduced nitrate leaching and improved soil moisture content without yield improvements in a four-year field study. Agric. Ecosyst. Environ. 237:80-94.

$\mathrm{Hu} \mathrm{L}, \mathrm{Wu}$ FP, DH, Chang SX, 2014. Wheat straw and its biochar had contrasting effects on soil $\mathrm{C}$ and $\mathrm{N}$ cycling two growing seasons after addition to a Black Chernozemic soil planted to barley. Biol. Fert. Soils 50:1291-9.

Huang Y, Zou JW, Zheng XH, Wang YS, Xu XK, 2004. Nitrous oxide emissions as influenced by amendment of plant residues with different C:N ratios. Soil Biol. Biochem. 36:973-81.

IGEWE, 2016. Institute of GeoSciences, Energy, Water and Enviroment.

Klute A, 1986. Methods of soil analysis. Part I - Physical and mineralogical methods. 2nd ed., ASA Monograph No 9, American Society of Agronomy, Madison, WI, USA.

Lee J, 2010. Effect of application methods of organic fertilizer on growth, soil chemical properties and microbial densities in organic bulb onion production. Sci. Hort. 124:299-305.

Lou Y, Xu M, Wang W, Sun X, Zhao K, 2011. Return rate of straw residue affects soil organic $\mathrm{C}$ sequestration by chemical fertilization. Soil Till. Res. 113:70-3.

Jordan C, Smith RV, 2005. Methods to predict the agricultural contributions to catchment nitrate loads: designation of nitrate vulnerable zones in Northern Ireland. Hydrobiologia 304:316-29.

Kammann CI, Linsel S, Gößling JW, Koyro HW, 2011. Influence of biochar on drought tolerance of Chenopodium quinoa Willd and on soil-plant relations. Plant Soil 345:195-210.

Kanthle AK, Lenka NK, Lenka S, Tedia K, 2016. Biochar impact on nitrate leaching as influenced by native soil organic carbon in an Inceptisol of central India. Soil Till. Res. 157:65-72.

Keeney DR, Nelson DW, 1982. Nitrogen inorganic forms. pp. $643-$ 653 in Methodology of soil analysis. American Society of Agronomy, Soil Science Society of America, USA.

Khan B, Lone IM, Ullah R, 2012. Effect of phosphatic fertilizers on chemical composition and total phosphorus uptake by wheat (Triticum aestivum L.). Int. J. Agric. Sci. Res. Tech. II:37-42.

Laird DA, Brown RC, Amonette JE, Lehmann J, 2009. Review of the pyrolysis platform for co-producing bio-oil and biochar. Biofuels Bioprod. Bior. 3:547-62.

Laird DA, Fleming P, Davis DD, Horton R, Wang B, Karlen DL, 2010. Impact of biochar amendments on the quality of a typical Midwestern agricultural soil. Geoderma 158:443-9.

Lehmann J, Joseph S, 2009. Biochar forenvironmental management: an introduction. Biochar Environ. Manage. 1:12.

Lehmann J, perera da Silva J, Steiner C, Nehls T, Zech W, Glaser B, 2003. Nutrient availability and leaching in an archaeological Anthrosol and a Ferralsol of the Central Amazon basin: fertiliz- 
er, manure and charcoal amendments. Plant Soil 249:43-357.

Liang B, Lehmann J, Solomon D, Kinyangi J, Grossman J, O’Neill B, Skjemstad JO; Thies J, Luizão FJ, Petersen J, Neves EG, 2006. Black carbon increases cation exchange capacityin soils.. Soil Sci. Soc. Am. J. 70:1719-30.

Libutti A, Monteleone M, 2017. Soil vs. groundwater: the quality dilemma. Managing nitrogen leaching and salinity control under irrigated agriculture in Mediterranean conditions. Agric. Water Manage. 186:40-50.

Libutti A, Mucci M, Francavilla M, Monteleone M, 2016. Effect of biochar amendment on nitrate retention in a silty clay loam soil. Ital. J. Agron. 11:273-6.

Malollari I, Bacu A, Bekteshi A, Babani F, Uku S, 2012. Nutrition factors of the Shkodra Lake waters and their distribution. J. Environ. Prot. Ecol. 13:532.

Major J, Lehmann J, Rondon M, Goodale C, 2009. Fate of soilapplied black carbon: downward migration, leaching and soil respiration. Global Change Biol. 16:1366-79.

McTaggart IP, Smith KA, 1993. Estimation of potentially mineralisable nitrogen in soil by $\mathrm{KCl}$ extraction. Comparison with soil $\mathrm{N}$ uptake in the field. Plant Soil 2:175-84.

Meisinger JJ, Delgado JA, 2002. Principles for managing nitrogen leaching. J. Soil Water Conserv. 57:485-98.

Mesi DA, Kopliku D, 2013. Toxicity bio-monitoring of Shkodra Lake surface water using a higher plant assay. Acad. J. Interdiscipl. Stud. 2:133-40.

METHOD 3051A, 2007. Microwave assisted acid digestion of sediments, sludges, soils, and oils.

Molenat J, Gascuel-Odoux C, 2002. Nitrate export from an agricultural basin: control mechanisms and nitrate residence times. Agricultural Effects on Ground and Surface Waters. Research at the Edge of Science Society, Wageningen, IAHS Pub, 273.

Monlau F, Francavilla M, Sambusiti C, Antoniou N, Solhy A, Libutti A, Zabaniotou A, Barakat A, Monteleone M, 2016. Toward a functional integration of anaerobic digestion and pyrolysis for a sustainable resource management. Comparison between solid-digestate and its derived pyrochar as soil amendment. Appl. Energy 169:652-62.

Monteleone M, Garofalo P, Cammerino ARB, Libutti A, 2015. Cereal straw management: a trade-off between energy and agronomic fate. Ital. J. Agron. 10:655.

Mulumba L, Lal R, 2008. Mulching effects on selected soil physical properties. Soil Till. Res. 98:106-11.

Murphy J, Riley JP, 1962. A modified single solution method for the determination of phosphate in natural waters. Anal. Chim Acta 27:31-6.

Nishio T, Oka N, 2003. Effect of organic matter application on the fate of $15 \mathrm{~N}$-labeled ammonium fertilizer in an upland soil. Soil Sci. Plant Nutr. 49:397-403.

Nolan BT, 2001. Relating nitrogen sources and aquifer susceptibility to nitrate in shallow groundwaters of the United States. Groundwater 39:290-9.

Perovic A, Bushati N, Nikcevic S, Pesic V, Karaman G, Seiler TB, Maric D, Rastall A, Erdinger L, Hollert H, 2004. Integrative assessment of sediments of the Lake Skadar/Shkodra using a triad approach. Proc. Annual Meeting of SETAC Europe, Prague, Czech Republic.

Puckett LJ, Tesoriero AJ, Dubrovsky NM, 2011. Nitrogen contamination of surficial aquifers-a growing legacy. Environ. Sci. Technol. 45:839-44.

Rakocevic-Nedovic J, Hollert H, 2005. Phytoplankton community and its pigment characteristics as trophic indexes of the Skadar Lake (Montenegro, Balkan). ESPR Environ. Sci. Pollut. Res. 12:146-52.

Rastall A, Neziri A, Vukovic Z, Jung C, Mijovic S, Hollert H, Nikcevic S, Erdinger L, 2004. The Identification of Readily Bioavailable Pollutants in Lake Shkodra/Skadar Using Semipermeable Membrane Devices (SPMDs), Bioassays and Chemical Analysis. ESPR - Environ. Sci. Pollut. Res. 11:240-53.

Rivett MO, Buss SR, Morgan P, Smith JWN, Bemment CD, 2008. Nitrate attenuation in groundwater: a review of biogeochemical controlling processes. Water Res. 42:215-32.

Saroa G, Lal R, 2003. Soil restorative effects of mulching on aggregation and carbon sequestration in a Miamian soil in central Ohio. Land Degrad. Dev. 14:481-93.

Schindler DW, 2006. Recent advances in the under standing and management of eutrophication. Limnol. Oceanogr. 51:356-63.

Singh BP, Hatton BJ, Singh B, Cowie AL, Kathuria A, 2010. Influence of biochars on nitrous oxide emission and nitrogen leaching from two contrasting soils. Environ. Qual. 39:1224-35.

Singh B, Camps-Arbestain M, Lehmann J, 2017. Available nutrients in biochar. In: Biochar: a guide to analytical methods. CRC Press, CSIRO Publishing, Boca Raton, FL, USA.

Shindo H, Nishio T, 2005. Immobilization and remineralization of $\mathrm{N}$ following addition of wheat straw into soil: determination of gross $\mathrm{N}$ transformation rates by $15 \mathrm{~N}$-ammonium isotope dilution technique. Soil Biol. Biochem. 37:425-32.

Skarbøvik E, Perovic A, Shumka S, Nagothu SU, 2014. Nutrient inputs, trophic status and water management challenges in the transboudary lake Skadar/Shkodra, Western Balkans. Arch. Biol. Sci. 66:667-81.

Steinbess S, Gleixner G, Antonietti M, 2009. Effect of biochar amendment on soil carbon balance and soil microbial activity. Soil. Biol. Biochem. 41:1301-10.

Tan D, Jin J, Huang S, Li S, He P, 2007. Effect of long-term application of $\mathrm{K}$ fertilizer and wheat straw to soil on crop yield and soil $\mathrm{K}$ under different planting systems. Agric. Sci. China, 6:200-7.

Taylor and Francis Group, 1998. Reference methods for plant analysis. CRC Press, Boca Raton, Boston, London, New York, Washington, D.C., USA.

Thomsen IK, Christensen BT, 1998. Cropping system and residue management effects on nitrate leaching and crop yields. Agricult. Ecosyst. Environ. 68:73-84.

Tong X, Xu M, Wang X, Bhattacharyya R, Zhang W, Cong R, 2014. Long-term fertilization effects on organic carbon fractions in ared soil of China. Catena 113:251-9.

UNEP/MAP/MED POL, 2005. Sampling and analysis techniques for the eutrophication monitoring strategy of Med Pol. Athens, Greece.

Vitousek PM, Aber JD, Howarth RW, Likens GE, Matson PA, Schindler DW, Schelesinger WH, Tilman DG, 1997. Human alteration of the global nitrogen cycle sources and consequences. Ecol. Appl. 7:737-50.

Walkley A, Black IA, 1934. An examination of the Degtjareff method for determining soil organic matter and a proposed modification of the chromic acid titration method. Soil Sci. 37:29-38.

Ward MH, de Kok TM, Levallois P, Brender J, Gulis G, Nolan BT, VanDerslice J, 2005. Workgroup report: drinking-water nitrate and health-recent findings and research needs. Environ. Health Perspect. 113:1607-14. 
WHO, 2004. World Health Organisation of the United Nations: guidelines for drinking-water quality, 3rd ed., vol. 1. Recommendations. Chemical aspects. Geneva. Available from: http://www.who.int/water_sanitation_health/dwq/GDWQ2004 web

Wolfe AH, Patz JA, 2002. Reactive nitrogen and human health: acute and long-term implications. Ambio 31:120-5.
WRB IWG, 2015. International soil classification system for naming soils and creating legends for soil maps. World Reference Base for Soil Resources 2014. Rome, Italy.

Yao Y, Gao B, Zhang M, Inyang M, Zimmerman AR, 2012. Effect of biochar amendment on sorption and leaching of nitrate, ammonium, and phosphate in a sandy soil. Chemosphere 89:1467-71. 